\title{
VERNALISATION IMPACT ON BIOMETRICAL PARAMETERS OF FESTULOLIUM VARIETIES
}

Evaldas KLIMAS, Institute of Agriculture and Food Science, Faculty of Agronomy, Aleksandras Stulginskis University. Studentu g. 11, Akademija LT-53361, Kauno r., Lithuania. evaldas.klimas@asu.lt

Jolanta LELIÜNIENĖ, Institute of Agriculture and Food Science, Faculty of Agronomy, Aleksandras Stulginskis University. Studentų g. 11, Akademija LT-53361, Kauno r., Lithuania. jolanta.leliuniene@asu.lt

Ligita BALEŽENTIENĖ, Institute of Environment and Ecology, Faculty of Forest Sciences and Ecology, Aleksandras Stulginskis University. Studentų g. 11, Akademija LT-53361, Kauno r., Lithuania. ligita.balezentiene@ asu.It (corresponding author)

\begin{abstract}
Many plants, including Festulolium, grown in temperate climates require vernalization and must experience a period of low winter temperature to initiate or accelerate the flowering process. The aim of research was to investigate impact of vernalisation thermoinduction on growth and development parameters of Festulolium varieties 'Vètra' and 'Punia DS'.

Investigations were carried out in Lithuanian Research Centre for Agriculture and Forestry Institute of Horticulture, Plant Physiology Laboratory of phytotron complex in 2011-2012. Some peculiarities of growth and development of. Festulolium varieties 'Vètra' and 'Punia DS' were investigated. 5 plants were sown in each 5 litre pot in neutral peat substrate ( $\mathrm{pH} 6-6.5)$. The plants were grown in greenhouse till the tillering phase at the temperature of $20 \pm 2{ }^{\circ} \mathrm{C}$ at daytime and $16 \pm 2{ }^{\circ} \mathrm{C}$ at night. Later plants were moved to low temperature chambers for 90,110 and 130 days for passing of vernalisation processes, where the 8 and 16 hour photoperiod were maintained at $4{ }^{\circ} \mathrm{C}$ temperature. After vernalisation periods plants were removed to a greenhouse for additional 20 days. Biometric parameters, namely plant height, shoot number and dry mass were measured after each period in greenhouse and climatic chambers. The data revealed different response of Festulolium varieties 'Vètra' and 'Punia DS' to vernalisation conditions. According to our data 'Vètra' plant height was $6 \%$ higher than the 'Punia DS' after 130+20 days of vernalisation. Nonetheless, vernalisation temperature conditions have no significant impact on shoot number. 110 and 130 long-day photoperiod significantly impacted on shoot number of Festulolium 'Vètra'. Otherwise, 90 days vernalisation of both photoperiod induced significantly the highest length of 'Punia DS' shoots. 'Vètra' accumulated significantly the maximum dry matter after 110 days vernalisation period, than that after 90 and 130 days.
\end{abstract}

Keywords: Festulolium, vernalisation, photoperiod, morphometry

\section{INTRODUCTION}

For successful reproduction of the perennial forage grass Festulolium we need to guarantee high seed yield production. However, the reproductive development of the Festulolium is regulated by a complex set of interacting environmental factors including low temperatures. This process also might be called thermoinduction (Duchovskis, 2004) or vernalisation (Michaels, Amasino, 2000) and ensures reproductive development and seed production. Gassner (1918) is usually cited as the first report that a wide range of plant species require cold exposure to flower. Processes that require prolonged exposure to cold, such as vernalisation and the cold-induced release of bud dormancy, stand in contrast with cold acclimation, a process designed to rapidly respond to cold (Thomashow, 2001). Typical vernalisation temperatures are between 5 and $10{ }^{\circ} \mathrm{C}$ (Amasino, 2004). Many plants grown in temperate climates require vernalisation and must experience a period of low winter temperature to initiate or accelerate the flowering process.

The main environmental factors which regulate plant shift from vegetative growth to generative development are temperature and photoperiod during vernalisation. Many physiological processes and plant development model are subjected on light (Chory et al., 1996). Light determinates germination, intensity of growth and maturity, plant productivity, nutritive value, habit, etc. there are two photoreceptor systems in plant, i.e. photomorphogenetical and photosynthetical. Their functioning depends on photoperiod, light density and spectral composition (Ames, Johnson, 1985). Thus, all conditions which increase photosynthetic potential (light, moisture, nutrients, plant density, etc.) will be scientifically validated and guarantee plant productivity (Trevaskis et al., 2007). Plant agrobiological potential is reliant on vernalisation conditions during the initial stages of ontogenesis. To manage and optimise plant morphogenesis and productivity we need to know these processes and conditions important for its formation. Biomass increase, root and shoot parameters are changed during plant growth (Michaels, Amasino, 2000). Therefore it is essential to know the response of development and morphometric parameters of Festulolium varieties to vernalisation conditions.

Copyright (C) 2017 The Authors. Published by Aleksandras Stulginskis University. This is an open-access article distributed under the terms of the Creative Commons Attribution License (CC-BY 4.0), which permits unrestricted use, distribution, and reproduction in any medium, provided the original author and source are credited. 
The aim of research was to investigate impact of vernalisation thermoinduction on growth and development parameters of Festulolium varieties 'Vètra' and 'Punia DS'.

\section{METHODS AND MATERIALS}

The evaluation of intertribal hybrids 'Vètra' ir 'Punia DS' of Festulolium (Poaceae) was developed in Institute of Agriculture, Lithuanian Research Centre for Agriculture and Forestry. These Festulolium cultivars were enlisted in the National list of Plant Varieties (1998 and 2008 respectively). Vernalisation impact on biometric parameters of 'Vètra' and 'Punia DS' was investigated in phytotron complex at the Plant Physiology Laboratory of the Institute of Horticulture, Lithuanian Research Centre for Agriculture and Forestry, in 2011-2012. Five plants of each cultivar were sown in each $5 \mathrm{~L}$ pot in peat substrate ( $\mathrm{pH}$ 6-6.5) in three replications (Fig. 1). The plants were grown in greenhouse till the tillering stage at the temperature of $20 \pm 2{ }^{\circ} \mathrm{C}$ and 16 hours photoperiod. Later 3 pots kept in greenhouse and others were moved to $4{ }^{\circ} \mathrm{C}$ low temperature growth chambers for 90,110 and 130 days for passing of vernalisation processes, where the 8 and 16 hour (h) photoperiods were maintained. After vernalisation periods plants were removed to a greenhouse $\left(20 \pm 2{ }^{\circ} \mathrm{C}\right.$ and 16 hours photoperiod) for additional 20 days.

Growth and organogenesis stages (I-XII) were identified in lines with Kuperman et al. (1982). Biometric parameters, namely plant height $(\mathrm{cm})$, shoot number (un.), and dry mass $(\mathrm{g})$ were measured were performed after each period in greenhouse and climatic chambers.
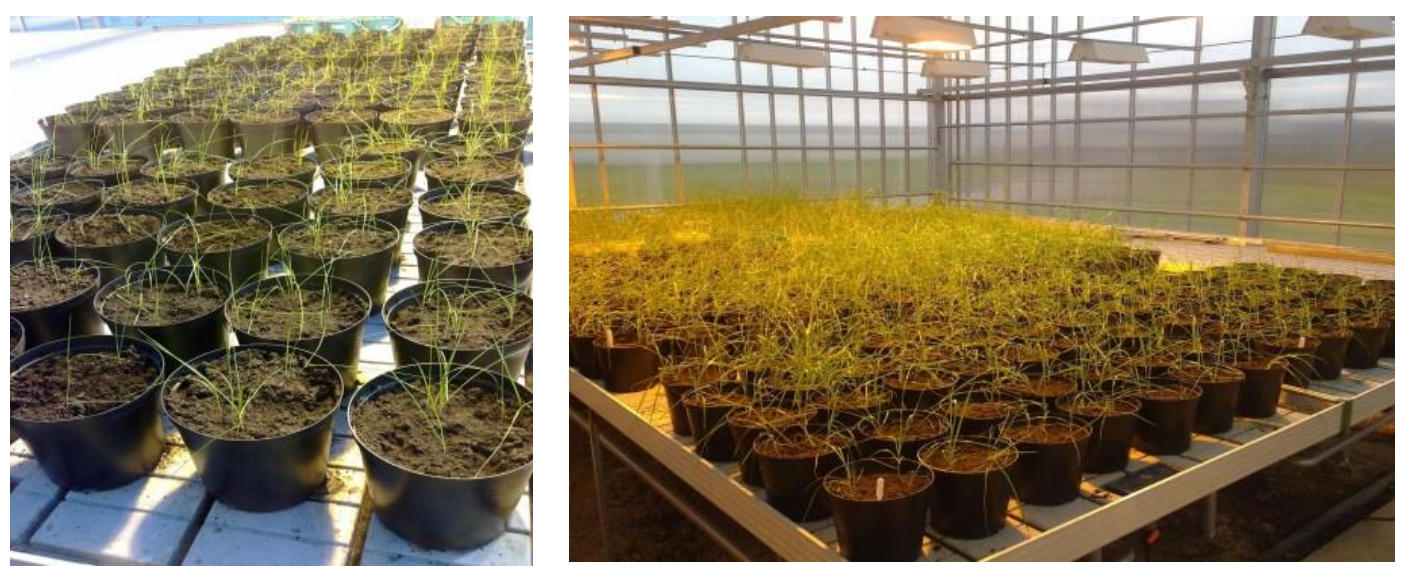

Figure 1. Festulolium 'Vètra' and 'Punia DS' in the phytotron complex

Statistical analysis. The confidence limits of the data were based on dispersion analyse method and evaluated using the ANOVA post-hoc Fisher $F$-criterion test. Standard error between treatments evaluated using MS Excel. The results were statistically evaluated using the statistical package STATISTICA of Stat Soft.

\section{RESULTS AND DISCUSSION}

The experiment revealed that Festulolium 'Vètra' vegetative shoots were significantly lower after long and short photoperiod and low positive temperature than that of plants grown continuously in conditions of long photoperiod and high temperature (greenhouse) (Table 1-3). 'Vètra' achieved tillering stage, $55 \mathrm{~cm}$ height, 11.3 shoot number and $2.05 \mathrm{~g}$ after 90 short-days vernalisation. Nonetheless, after 90 long-days vernalisation these parameters were lower due to achieved just leaf development stage.

Table 1. Impact of different photoperiod 90-days vernalisation on 'Vètra' growth and development (*P $\geq 0.05)$

\begin{tabular}{|c|c|c|c|c|c|c|}
\hline \multicolumn{2}{|c|}{ Vernalisation } & \multirow{2}{*}{$\begin{array}{l}\text { Organogenesis } \\
\text { stage }\end{array}$} & \multirow[t]{2}{*}{ Growth stage } & \multirow{2}{*}{$\begin{array}{c}\text { Plant height, } \\
\mathrm{cm}\end{array}$} & \multirow{2}{*}{$\begin{array}{c}\text { Shoot number, } \\
\text { un. }\end{array}$} & \multirow{2}{*}{$\begin{array}{c}\text { Dry mass, } \\
\mathrm{g}\end{array}$} \\
\hline Duratio & Photoperiod, h; Temperature, ${ }^{\circ} \mathrm{C}$ & & & & & \\
\hline \multirow[t]{3}{*}{90} & $16 \mathrm{~h}, 20^{\circ} \mathrm{C}$ (greenhouse) & VII & Stem elongation & $89.5 *$ & 31.3 & 10.07 \\
\hline & $8 \mathrm{~h}, 4^{\circ} \mathrm{C}$ & IV & Tillering & 55.0 & 11.3 & 2.05 \\
\hline & $16 \mathrm{~h}, 4^{\circ} \mathrm{C}$ & II & Leaf development & 18.3 & 10.3 & 0.98 \\
\hline \multirow[t]{3}{*}{$90+20$} & $16 \mathrm{~h}, 20^{\circ} \mathrm{C}$ (greenhouse) & VII & Stem elongation & 89.5 & 31.3 & 10.07 \\
\hline & $8 \mathrm{~h}, 4^{\circ} \mathrm{C}$ & $\mathrm{V}$ & Booting & 64.0 & 37.0 & 12.15 \\
\hline & $16 \mathrm{~h}, 4^{\circ} \mathrm{C}$ & V & Booting & 50.8 & 18.3 & 4.18 \\
\hline
\end{tabular}

Festulolium 'Vètra' exhibited positive response to 110 and 130 long-days vernalisation, which induced plant height and other plant growth parameters (Table 2, 3). Plant height increased from 47 to $54 \mathrm{~cm}$ after 110 (short- and long-day vernalisation, respectively. Nonetheless, shoot number and dry mass recorded bigger at short- day photoperiod than at longday item. 
Table 2. Impact of different photoperiod 110-days vernalisation on 'Vètra' growth and development $(* \mathrm{P} \geq 0.05)$

\begin{tabular}{|c|c|c|c|c|c|c|}
\hline \multicolumn{2}{|r|}{ Vernalisation } & \multirow{2}{*}{$\begin{array}{l}\text { Organogenesis } \\
\text { stage }\end{array}$} & \multirow[t]{2}{*}{ Growth stage } & \multirow{2}{*}{$\begin{array}{l}\text { Plant height, } \\
\mathrm{cm}\end{array}$} & \multirow{2}{*}{$\begin{array}{l}\text { Shoot number, } \\
\text { un. }\end{array}$} & \multirow{2}{*}{$\begin{array}{c}\text { Dry mass, } \\
\mathrm{g}\end{array}$} \\
\hline Duration, day & Photoperiod, h; Temperature, ${ }^{\circ} \mathrm{C}$ & & & & & \\
\hline \multirow[t]{3}{*}{110} & $16 \mathrm{~h}-20^{\circ} \mathrm{C}$ (greenhouse) & $\mathrm{X}$ & Milky stage & $86.6^{*}$ & 24.0 & 9.93 \\
\hline & $8 \mathrm{~h}-4^{\circ} \mathrm{C}$ & III & Tillering & 47.0 & 27.3 & 3.69 \\
\hline & $16 \mathrm{~h}-4^{\circ} \mathrm{C}$ & III & Tillering & 54.0 & 12.6 & 2.19 \\
\hline \multirow[t]{3}{*}{$110+20$} & $16 \mathrm{~h}-20^{\circ} \mathrm{C}$ (greenhouse) & $\mathrm{X}$ & Milky stage & 86.6 & 24.0 & 9.93 \\
\hline & $8 \mathrm{~h}-4^{\circ} \mathrm{C}$ & V & Booting & 52.6 & 33.0 & 4.84 \\
\hline & $16 \mathrm{~h}-4^{\circ} \mathrm{C}$ & V & Booting & 62.3 & 32.7 & 2.46 \\
\hline
\end{tabular}

Temperature and photoperiod of 130 days vernalisation did not exhibited significant impact on 'Vètra' growth parameters (Table 3). However, after the longest 130-days vernalisation plants succeeded flowering and heading stages.

Table 3. Impact of different photoperiod 130-days vernalisation on 'Vètra' growth and development (*P $\geq 0.05)$

\begin{tabular}{|c|c|c|c|c|c|c|}
\hline \multicolumn{2}{|c|}{$\begin{array}{l}\text { Vernalisation } \\
\end{array}$} & \multirow{2}{*}{$\begin{array}{l}\text { Organogenesis } \\
\text { stage }\end{array}$} & \multirow[t]{2}{*}{ Growth stage } & \multirow{2}{*}{$\begin{array}{c}\text { Plant height, } \\
\mathrm{cm}\end{array}$} & \multirow{2}{*}{$\begin{array}{c}\text { Shoot number, } \\
\text { un. }\end{array}$} & \multirow{2}{*}{$\begin{array}{c}\text { Dry mass, } \\
\mathrm{g}\end{array}$} \\
\hline Duration, day & Photoperiod, h; Temperature, ${ }^{\circ} \mathrm{C}$ & & & & & \\
\hline \multirow[t]{3}{*}{130} & $16 \mathrm{~h}-20^{\circ} \mathrm{C}$ (greenhouse) & XII & Hard dough & $104.0 *$ & 34.7 & $17.36^{*}$ \\
\hline & $8 \mathrm{~h}-4^{\circ} \mathrm{C}$ & III & Tillering & 28.3 & 28.3 & 2.97 \\
\hline & $16 \mathrm{~h}-4^{\circ} \mathrm{C}$ & III & Tillering & 43.0 & 16.3 & 0.18 \\
\hline \multirow[t]{3}{*}{$130+20$} & $16 \mathrm{~h}-20{ }^{\circ} \mathrm{C}$ (greenhouse) & IX & Flowering & 104.0 & 29.5 & 9.76 \\
\hline & $8 \mathrm{~h}-4^{\circ} \mathrm{C}$ & VIII & Heading & 55.0 & 30.0 & 2.99 \\
\hline & $16 \mathrm{~h}-4^{\circ} \mathrm{C}$ & VII & Stem elongation & 67.6 & 24.3 & 5.09 \\
\hline
\end{tabular}

Plant height of Festulolium 'Punia DS' insignificantly responded to vernalization conditions (Table 4). One of parental form of this variety was frost-resistant meadow fescue (Kosmala et al., 2007), therefore 90-days vernalisation induced significantly the highest shoots $(51.3-51.6 \mathrm{~cm})$ than that after 110 and 130 days vernalisation. After 90 days vernalisation additional plant growing in greenhouse induced increase of shoot number and biomass.

Table 4. Impact of different photoperiod 90-days vernalisation on 'Punia DS' growth and development (*P $\geq 0.05)$

\begin{tabular}{|c|c|c|c|c|c|c|}
\hline \multicolumn{2}{|r|}{ Vernalisation } & \multirow{2}{*}{$\begin{array}{l}\text { Organogenesis } \\
\text { stage }\end{array}$} & \multirow[t]{2}{*}{ Growth stage } & \multirow{2}{*}{$\begin{array}{l}\text { Plant } \\
\text { height, } \\
\mathrm{cm}\end{array}$} & \multirow{2}{*}{$\begin{array}{l}\text { Shoot } \\
\text { number, } \\
\text { un. }\end{array}$} & \multirow{2}{*}{$\begin{array}{l}\text { Dry } \\
\text { mass, } \\
\mathrm{g}\end{array}$} \\
\hline $\begin{array}{l}\text { Duration, } \\
\text { day }\end{array}$ & $\begin{array}{l}\text { Photoperiod, h; Temperature, } \\
{ }^{\circ} \mathrm{C}\end{array}$ & & & & & \\
\hline \multirow[t]{3}{*}{90} & $16 \mathrm{~h}-20{ }^{\circ} \mathrm{C}$ (greenhouse) & VII & Stem elongation & $61.0 *$ & 25.0 & 3.58 \\
\hline & $8 \mathrm{~h}-4^{\circ} \mathrm{C}$ & III & Tillering & $51.3^{*}$ & 14.7 & 1.53 \\
\hline & $16 \mathrm{~h}-4^{\circ} \mathrm{C}$ & II & $\begin{array}{l}\text { Leaf } \\
\text { development }\end{array}$ & $51.6^{*}$ & 11.0 & 1.01 \\
\hline \multirow[t]{3}{*}{$90+20$} & $16 \mathrm{~h}-20^{\circ} \mathrm{C}$ (greenhouse) & VII & Stem elongation & 61.0 & 25.0 & 3.58 \\
\hline & $8 \mathrm{~h}-4^{\circ} \mathrm{C}$ & V & Booting & 58.0 & 32.0 & 5.22 \\
\hline & $16 \mathrm{~h}-4^{\circ} \mathrm{C}$ & $\mathrm{V}$ & Booting & 58.0 & 23.0 & 4.45 \\
\hline
\end{tabular}

After 110 days vernalisation the shoot height of Festulolium 'Punia DS' was smaller by 1.8 times at short-day and by 1.9 times at long-day photoperiod than that of plants continuously grown in greenhouse (Table 5). Shoot number and mass was also smaller after vernalisation than in Control treatment (greenhouse).

Table 5. Impact of different photoperiod 110-days vernalisation on 'Punia DS' growth and development (*P $\geq 0.05)$

\begin{tabular}{|c|c|c|c|c|c|c|}
\hline \multicolumn{2}{|r|}{ Vernalisation } & \multirow{2}{*}{$\begin{array}{l}\text { Organogenesis } \\
\text { stage }\end{array}$} & \multirow[t]{2}{*}{ Growth stage } & \multirow{2}{*}{$\begin{array}{l}\text { Plant height, } \\
\mathrm{cm}\end{array}$} & \multirow{2}{*}{$\begin{array}{c}\text { Shoot number, } \\
\text { un. }\end{array}$} & \multirow{2}{*}{$\begin{array}{c}\text { Dry mass, } \\
\mathrm{g}\end{array}$} \\
\hline Duration, day & Photoperiod, h; Temperature, ${ }^{\circ} \mathrm{C}$ & & & & & \\
\hline \multirow[t]{3}{*}{110} & $16 \mathrm{~h}-20^{\circ} \mathrm{C}$ (greenhouse) & $\mathrm{X}$ & Milky stage & $100.5^{*}$ & 27.5 & 7.47 \\
\hline & $8 \mathrm{~h}-4^{\circ} \mathrm{C}$ & III & Tillering & 42.3 & 16.0 & 0.82 \\
\hline & $16 \mathrm{~h}-4^{\circ} \mathrm{C}$ & III & Tillering & 41.0 & 9.00 & 0.73 \\
\hline \multirow[t]{3}{*}{$110+20$} & $16 \mathrm{~h}-20^{\circ} \mathrm{C}$ (greenhouse) & $\mathrm{X}$ & Milky stage & $100.5^{*}$ & 27.5 & 7.47 \\
\hline & $8 \mathrm{~h}-4^{\circ} \mathrm{C}$ & V & Booting & 54.6 & 31.7 & 4.20 \\
\hline & $16 \mathrm{~h}-4^{\circ} \mathrm{C}$ & $\mathrm{V}$ & Booting & 50.6 & 27.0 & 1.47 \\
\hline
\end{tabular}

'Punia DS' height was documented by $1.0 \mathrm{~cm}$ shorter after 130 long-days photoperiod than that of short-day photoperiod (Table 6). Nonetheless, 130 short-day vernalisation increased shoot number and biomass of 'Punia DS' as compared with long-day vernalisation. 
Table 6. Impact of different photoperiod 130-days vernalisation on 'Punia DS' growth and development (*P $\geq 0.05)$

\begin{tabular}{|c|c|c|c|c|c|c|}
\hline \multicolumn{2}{|r|}{ Vernalisation } & \multirow{2}{*}{$\begin{array}{l}\text { Organogenesis } \\
\text { stage }\end{array}$} & \multirow[t]{2}{*}{ Growth stage } & \multirow{2}{*}{$\begin{array}{l}\text { Plant height, } \\
\mathrm{cm}\end{array}$} & \multirow{2}{*}{$\begin{array}{l}\text { Shoot number, } \\
\text { un. }\end{array}$} & \multirow{2}{*}{$\begin{array}{c}\text { Dry mass, } \\
\mathrm{g}\end{array}$} \\
\hline Duration, day & Photoperiod, h; Temperature, ${ }^{\circ} \mathrm{C}$ & & & & & \\
\hline \multirow{3}{*}{130} & $16 \mathrm{~h}-20{ }^{\circ} \mathrm{C}$ (greenhouse) & $\mathrm{V}$ & Booting & 50.0 & 30.0 & 2.98 \\
\hline & $8 \mathrm{~h}-4^{\circ} \mathrm{C}$ & III & Tillering & 48.0 & 26.7 & 2.41 \\
\hline & $16 \mathrm{~h}-4^{\circ} \mathrm{C}$ & IV & Tillering & 47.0 & 14.0 & 0.92 \\
\hline \multirow{3}{*}{$130+20$} & $16 \mathrm{~h}-20^{\circ} \mathrm{C}$ (greenhouse) & XII & Hard dough & 98.0 & 23.7 & 8.15 \\
\hline & $8 \mathrm{~h}-4^{\circ} \mathrm{C}$ & III & Tillering & 58.6 & 21.0 & 3.75 \\
\hline & $16 \mathrm{~h}-4^{\circ} \mathrm{C}$ & IV & Tillering & 63.6 & 36.5 & 4.43 \\
\hline
\end{tabular}

Comparing the shoot number of Festulolium 'Punia DS' and 'Vètra' insignificant differences have been identified. Shoots number after a long-day photoperiod and low positive temperatures vernalisation was lower than that of plants constantly grown in the greenhouse (Control) at long day and high temperature conditions (Table 1-6). Festulolium inherited from ryegrass parental forms facultative requirement for low temperature and short photoperiod during flowering induction processes (Thomas et al., 2003), therefore photoperiod and thermoinduction effects only encourage plants to develop more synchronously and to form the generative organs. Organogenesis processes proceeded even at low temperature conditions.

\section{CONCLUSIONS}

It was revealed, that 110 and 130 long-day photoperiod significantly impacted on shoot number of Festulolium 'Vètra'. Otherwise, 90 days vernalisation of both photoperiod induced significantly the highest length of 'Punia DS' shoots. Nonetheless, vernalisation temperature conditions have no significant impact on shoot number.

'Vètra' accumulated significantly the maximum dry matter after 110 days vernalisation period, than that after 90 and 130 days.

Festulolium inherited optional need of low temperature and short photoperiod for flowering induction from ryegrass parental forms, and thus most genotypes formed the generative organs when have grown in constantly long-day and high temperatures conditions. Photo- and thermoinduction effects just encourage plants to develop synchronously and to form the generative organs of all genotypes. Organogenesis processes continued even in low temperatures conditions. It should be noted that more vigorous formation of prefloral structures 'Vètra' and 'Punia DS' plant needs short and long day conditions, respectively. This indicates that Festulolium cultivars of different origin need different photoperiod for the flowering induction.

\section{REFERENCES}

1. Amasino, R. 2004. Vernalization, competence, and the epigenetic memory of winter. The Plant Cell. Vol. 16, Iss. 10, pp. 2553-2559. https://doi.org/10.1105/tpc.104.161070.

2. Ames, M., Johnson, W.S. 1985. Factors affecting plant growth. Extension Service Horticulture, No, 2, pp.160.

3. Chory, J., Chatterjee, M., Cook, R.K., Elich, T., Fankhauser, C., Li, J., Nagpal, P., Neff, M., Pepper, A., Poole, D., Reed, J., Vitart, V. 1996. From seed germination to flowering, light controls plant development via the pigment phytochrome. Proceedings of the National Academy of Sciences. Vol. 93, No. 22, pp. 12066-12071. https://doi.org/10.1073/pnas.93.22.12066

4. Duchovskis, P. 2004. Flowering initiation of wintering plants. Sodininkystè ir daržininkystè. Vol. 23, No. 2, pp. 3-11.

5. Kosmala, A., Zwierzykowski, Z., Zwierzykowska, E., Łuczak, M., Rapacz, M., Gąsior, D., Humphreys, M.W. 2007. Introgression mapping of genes for winter hardiness and frost tolerance transferred from Festuca arundinacea into Lolium multiflorum. Journal of Heredity. Vol. 98, Iss. 4, pp.311-316. https://doi.org/10.1093/jhered/esm047

6. Kuperman, F.M., Rzhanova, E.I., Murashew, V.V., Lvova, I.N., Sedova, E.A., Ahundova, V.A., Scherbina, I.P. 1982. Development biology of crops. Vysshaya shkola, Moscow, 343 p. [in Russian]

7. Michaels, S.D., Amasino, R.M. 2000. Memories of winter: vernalization and the competence to flower. Plant, Cell and Environment. Vol. 23, Iss. 11, pp.1145-1153. https://doi.org/10.1046/j.1365-3040.2000.00643.X

8. Nacionalinis augalų veislių sąrašas. VAT, ŽŪM, 2008.

9. Thomas, H.M., Morgan, W.G., Humphreys, M.W. 2003. Designing grasses with a future-combining the attributes of Lolium and Festuca. Euphytica. Vol. 133, Iss. 1, pp. 19-26. https://doi.org/10.1023/A:1025694819031

10. Thomashow, M.F. 2001. So what's new in the field of plant cold acclimation? Lots! Plant Physiology. Vol. 125, Iss, 1, pp.89-93. https://doi.org/10.1104/pp.125.1.89

11. Trevaskis, B., Hemming, M.N., Dennis, E. S. 2007. The molecular basis of vernalization-induced flowering in cereals. Trends in Plant Science. Vol. 12, Iss. 8, pp. 352-357. https://doi.org/10.1016/j.tplants.2007.06.010 